E. N. RAZNATOVSKAYA (Zaporizhzhia, Ukraine)

\title{
EFFICIENCY OF ANTIMYCOBACTERIAL CHEMOTHERAPY IN THE REGISTERED CASES OF CHEMORESISTANCE TUBERCULOSIS OF LUNGS IN ZAPORIZHZHIA REGION
}

Zaporizhzhia State Medical University <raxnatovskaya@gmail.com>

\begin{abstract}
Nowadays chemoresistant pulmonary tuberculosis is an urgent medico-social problem, both in Ukraine, and around the world. It is established that the indicator of non-effective treatment of patients of pulmonary tuberculosis is influenced by the following factors: features of tuberculosis, personal characteristics of patients and their social status, organization of treatment. The objective of the work - to define efficiency of an antimycobacterial chemotherapy of the registered cases of a chemoresistant pulmonary tuberculosis in Zaporizhzhia region. Materials and methods of the research. The analysis of the registered 1571 cases of a chemoresistant pulmonary tuberculosis in Zaporizhzhia region during 2012-2016 is carried out. Serious associated diseases (HIV infection/AIDS, a diabetes mellitus, etc.) were criteria of an exception. Results. Among the analysed cases there were $75,1 \%$ men and $24,9 \%$ women. Nowadays in structure of a chemoresistant pulmonary tuberculosis males $(75,1 \%)$, people of riper years and working-age $(44,4 \%$ and $92,3 \%$, respectively) authentically prevail. Identification of a chemoresistant pulmonary tuberculosis happened authentically more often "at the address of patients to the doctor» (57,9\%) and «at inspection in a hospital concerning other disease» (35,2\%). On registration the a chemoresistant pulmonary tuberculosis groups of patients with new cases $(37,4 \%)$ and a recurrence of specific process $(26,5 \%)$, destructive process $(78,1 \%)$, a bacterioexcretion (98,3\%), multirefractory tuberculosis (76,3\%) and an infiltrative clinical form $(71,8 \%)$ prevailed. While today efficiency of treatment among the registered 1571 cases of a chemoresistant pulmonary tuberculosis in Zaporizhzhia region during 2012-2016 is 25,6\%, treatment is continued by another 27,4\% of patients. Some results are disturbing such as «treatment is interrupted》 and «treatment failure» which made on $17,6 \%$, and the high frequency (33,9\%) transfer to palliative treatment of patients with treatment failure.
\end{abstract}

Key words: antimycobacterial chemotherapy; chemoresistance tuberculosis; treatment outcome.

Introduction. For today chemoresistance tuberculosis of lungs (CRTL) is an urgent medico-social problem, both in Ukraine [6], and around the world [2, 7-11, 13, 14] that has an adverse effect on a demographic situation. Relevance of a problem of CRTL in our country is defined by the following adverse factors: high level of epidemic danger, low efficiency of treatment of patients, breaks in treatment, frequent emergence of a recurrence and high risk of a lethal effect $[3,4,6]$. The main thing and one of the most effective method of treatment of TB patients both with the kept sensitivity of micobacteria of tuberculosis (MBT), and with refractory strains, there are uses of a complex antimycobacterial chemotherapy $[6,13]$. The indicator of non-effective antimycobacterial treatment of suffering from tuberculosis lungs is influenced by the following factors: features of tuberculosis, personal characteristics of patients and their social status, organization of treatment [5]. The current of CRTL and efficiency of its treatment also depend on a profile of medicamental resistance. So, $50 \%$ of patients with polyresistance tuberculosis (PRTB) of lungs without the received treatment die within 5 years, and in $25 \%$ - process passes into a chronic form that is the reason of development in $95.5 \%$ of secondary resistance of MBT [14]. Result of "successful treatment" in the registered cases of multidrug-resistant tuberculosis (MDR-TB) of lungs in the world in 2012 is reached by $48 \%$ of patients [12]. Results of treatment of patients with expanded resistance (XDR-TB) on an indicator "treatment" are 3 times lower, than at sick with MDR-TB of lungs [1]. 
The object is to define efficiency of antimycobacterial chemotherapy in the registered cases of chemoresistance tuberculosis of lungs in Zaporizhzhia region.

Materials and methods. The analysis of indicators of the registered 1571 cases of CRTL is carried out in Zaporizhzhia region during 2012-2016 and data of the Register of TB patients. Criteria of including of patients in a research: existence of resistance of MBT to the antimycobacterial drugs and the transfer of patients to category 4 of the dispensary account. Serious associated diseases (HIV infection/AIDS, a diabetes mellitus, etc.) were criteria of an exception.

Efficiency of an antimycobacterial chemotherapy was estimated by results of treatment [4]: "cured" - the patient of category 4 who finished treatment respectively and has at least 5 consecutive negative results of seeding; "Treatment is complete" - the patient, who completely finished a course of treatment on category 4, however doesn't correspond to criterion "cured" due to the lack of results of a bacteriological research; "Treatment is interrupted" - the patient, who interrupted treatment for 2 months one after another or more any reasons; "Treatment failure" - treatment was stopped, or the regimen of treatment needs change at least of two antituberculous drugs due to the lack of conversion of a sputum at end of an intensive phase of treatment, existence of signs of in addition acquired resistance to fluoroquinolones or secondary injection drugs or existence of undesirable medicinal reactions; "I left" - the patient, who transferred to other region and results of his/her treatment are unknown; "I died" - sick category 4 who died of any reason during a case course of treatment; "Continues treatment" - the patient who continues treatment in category 4 today.

Results of a research are processed by modern methods of the analysis on the personal computer with use of a statistical package of the STATISTICA ${ }^{\circledR}$ for Windows 6.0 license program (Stat Soft Inc., No. AXXR712 D833214FAN5).

Results and their discussion. Among sick with CRTB of the lungs included in a research, there were 1180 men $(75,1 \%)$ and 391 women $(24,9 \%)$. The age gradation was carried out according to the classification of World Health Organization (1998): 18-29 years - young age, 30-44 years - mature age, 45-59 - middle age, 60-74advanced age, 75-89 - later age. So, at distribution of patients on age it is established that there were 300 persons of young age $(19,1 \%)$, mature age $-698(44,4 \%)$, middle age $-452(28,8 \%)$, advanced age $-114(73 \%)$ and later age $-7(0,4 \%)$. It is established that among sick with CRTB persons of mature age prevailed $\left(\chi^{2}=29,76\right.$; $\mathrm{P}<0,001)$, and the smallest - the number of persons of later age $\left(\chi^{2}=19,2\right.$; $\mathrm{P}<0,001)$.

Thus, in the age section among sick with CRTB persons mature prevailed (44,4\%). In $92,3 \%$ of cases there are persons of working-age.

Among sick with CRTL of rural areas there were 477 patients $(30,4 \%)$, the urban population has made $1035(65,9 \%), 59$ people $(3,7 \%)$ were without a certain residence. It is established that the urban population prevailed $\left(\chi^{2}=31,91 ; \mathrm{P}<0,001\right)$, and the smallest - the number of persons of no fixed abode $\left(\chi^{2}=26,31 ; \mathrm{P}<0,001\right)$.

In the analysis of social structure of sick of CRTL it is established that: $68,7 \%-$ jobless persons of working-age; $12,1 \%$ - the working persons; 7,9 \% - pensioners; 4,4 \% - disabled people; 3,7\% - the homeless; $1,4 \%$ - students; $0,9 \%$ - the persons exempted from serving sentence; $0,4 \%$ - the women who were on a maternity leave; $0,3 \%$ - the condemned persons; $0,2 \%$ - immigrants. As we see, quantity of socially unprotected segments of the population was $87,9 \%$ of cases, by 7,2 times more often than social protected $-12,1 \%\left(\chi^{2}=27,67 ; \mathrm{P}<0,001\right)$. The number of the persons abusing alcohol was 11,2 \% (176 patients), consumers of injecting drugs $-1,2 \%$ (19 patients).

The analysis of a type of detection of a disease has shown that the diagnosis is established during routine inspection in 94 people $(5,9 \%)$, at the address to the doc- 
tor - in $910(57,9 \%)$, at inspection in a hospital - in $551(35,2 \%)$ at inspection of the persons which were in contact with the patient $-3(0,2 \%)$, the rest -13 $(0,8 \%)$.

Thus, the main amount of sick with CRTL was found during the address to the doctor that made $57,9 \%$ of cases, and at inspection in a hospital concerning other disease $-35,2 \%$.

At distribution of patients on registration groups it agrees the anamnesis of the previous treatment or results of the cohort analysis of the previous treatment (tab. 1) it is established that the number of patients with for the first time the diagnosed tuberculosis (FDTB) was 37,4 \%, with a recurrence of specific process (RTB) - 26,5\%, with other cases $-7,3 \%$, the treatment after a break (TAB) $-5,7 \%$, with treatment after failure of the 1 st course of a chemotherapy (TAF of the 1st course CT) - 12,3\%, with treatment after failure of a repeated course of treatment (TAF RCT) $-10,7 \%$, transferred/arrived $-0,1 \%$.

Table 1. Distribution of sick with CRTL on registration groups according to the anamnesis of the previous treatment or results of the cohort analysis of the previous treatment

\begin{tabular}{l|c|c|c|c}
\hline \multirow{2}{*}{ Registration group } & \multicolumn{2}{c|}{ Quantity } & \multirow{2}{*}{$\chi^{2}$} & \multirow{2}{*}{ P } \\
\cline { 2 - 4 } & abs. & $\%$ & 37,9 & $<0,001$ \\
\hline \hline FDTB & 587 & 37,4 & 10,65 & $>0,05$ \\
RTB & 417 & 26.5 & 3,35 & $>0,05$ \\
Other cases & 115 & 7,3 & 5,08 & $>0,05$ \\
TAB & 89 & 5.7 & 0,25 & $>0,05$ \\
TAF of the 1st course of CT & 193 & 12.3 & 0,86 & $>0,05$ \\
TAF RCT & 169 & 10.7 & 14,4 & $<0,05$ \\
Transferred/arrived & 1 & 0.1 & & \\
Total & 1571 & 100 & & \\
\hline
\end{tabular}

Thus, among the registered cases of CRTL on registration groups patients with FDTB prevailed $\left(\chi^{2}=37,9 ; \mathrm{P}<0,001\right)$.

Existence of destructive process is registered in 1227 sick with CRTB (78,1\%), and bacterioexcretion - in 1545 (98,3 \%). Distribution of sick with CRTL by the form of medicamental resistance (tab. 2) is carried out. It is established that the frequency of sick with MDR-TB was 76,3\%, with RRTB - 15 MDR-TB $2 \%$, with tuberculosis, which is refractory to Rifampicinum (РifТБ) $-7,4 \%$, with PRTB $-0,8 \%$, with risk of multirefractory tuberculosis (RMDR-TB) contact - 0,3\%.

Table 2. Distribution of sick with CRTL by the form of medicamental resistance

\begin{tabular}{|c|c|c|c|c|}
\hline \multirow{2}{*}{ Form of medicamental resistance } & \multicolumn{2}{|c|}{ Quantity } & \multirow{2}{*}{$\chi^{2}$} & \multirow{2}{*}{$\mathrm{P}$} \\
\hline & abs. & $\%$ & & \\
\hline MDR-TB & 1198 & 76,3 & 158,48 & $<0,001$ \\
\hline XDR-TB & 239 & 15,2 & 1,15 & $>0,05$ \\
\hline RifTB & 117 & 7,4 & 7,93 & $>0,05$ \\
\hline PRTB & 12 & 0,8 & 18,43 & $<0,005$ \\
\hline RMDR-TB & 5 & 0,3 & 19,4 & $<0,001$ \\
\hline Total & 1571 & 100 & 205,39 & \\
\hline
\end{tabular}

So, in accordance with the form of medicamental resistance sick of MDR-TB of lungs prevailed $\left(76,3 \% ; \chi^{2}=158,48 ; \mathrm{P}<0,001\right)$.

Distribution of sick with CRTL according to clinical forms (tab. 3) showed that the infiltrative form took place in $71,8 \%$ of cases, focal - in $0,8 \%$, disseminated - in 
$21,1 \%$, caseous pneumonia - in $0,5 \%$, fibrous and cavernous process - in 4,9\%, miliary tuberculosis was diagnosed - in $0,8 \%$, cirrhotic - in $0,1 \%$.

Table 3. Distribution of sick with CRTL according to clinical forms

\begin{tabular}{l|c|c|c|c}
\hline \multirow{2}{*}{ Clinical form } & \multicolumn{2}{c|}{ Quantity } & \multirow{2}{*}{$\chi^{2}$} & \multirow{2}{*}{$\mathrm{P}$} \\
\cline { 2 - 3 } & abs. & $\%$ & 233,64 & $<0,001$ \\
\hline \hline infiltrative & 1129 & 71,8 & 12,64 & $<0,05$ \\
focal & 12 & 0,8 & 3,35 & $>0,05$ \\
disseminated & 331 & 21,1 & 13,21 & $<0,05$ \\
caseous pneumonia & 8 & 0,5 & 6,09 & $>0,05$ \\
fibrous and cavernous process & 78 & 4,9 & 12,64 & $<0,05$ \\
miliary tuberculosis & 12 & 0,8 & 14 & $<0,05$ \\
cirrhotic & 1 & 0,1 & & \\
Total & 1571 & 100 & & \\
\hline
\end{tabular}

According to the tab. 3 testify, there are prevailed among clinical forms at sick with CRTB - infiltrative form $\left(71,8 \% ; \chi^{2}=233,64 ; \mathrm{P}<0,001\right)$. Liquid clinical forms of specific process at sick with CRTL appeared: focal $\left(\chi^{2}=12,64 ; \mathrm{P}<0,05\right)$, caseous pneumonia $\left(\chi^{2}=13,21 ; \mathrm{P}<0,05\right)$ and miliary tuberculosis $\left(\chi^{2}=12,64 ; \mathrm{P}<0,05\right)$.

The average term of duration of hospitalization made $(1,24 \pm 0,02)$ years.

At determining efficiency of antimycobacterial chemotherapy among the registered cases of CRTL it is established that 190 patients with results "cured" $(12.1 \%)$ finished treatment with a results "cured" $\left(\chi^{2}=0,31 ; \mathrm{P}<0,05\right), 212(13,5 \%)$ - with "treatment is complete" $-\left(\chi^{2}=0,03 ; \mathrm{P}<0,05\right), 276$ people $(17,6 \%)$ are registered as "treatment is interrupted" $\left(\chi^{2}=0,81 ; \mathrm{P}<0,05\right), 277(17,6 \%)$ - with "treatment failure" (NLTB) $\left(\chi^{2}=0,81 ; \mathrm{P}<0,05\right), 430(27,4 \%)$ - with "continues treatment" $\left(\chi^{2}=12,27 ; \mathrm{P}<0,05\right)$, $18(1,1 \%)$ - "left" $\left(\chi^{2}=12,08 ; \mathrm{P}<0,05\right)$ and also "died" - $168(10,7 \%)\left(\chi^{2}=0,86\right.$; $\mathrm{P}<0,05)$.

Thus, the authentic difference between results of treatment among sick with CRTL isn't revealed. But high frequency of results of treatment is concerning as "treatment is interrupted" and "treatment failure" made 17,6\%. And in structure of cases of CRTL with NTTB, 94 patients $(33,9 \%)$ were transferred to palliative treatment, made $5.9 \%$ in the general structure of CRTB.

Conclusions. For today in structure of CRTL males $(75,1 \%)$, persons of a mature age $(44,4 \%)$ prevailed. $65,9 \%$ were city dwellers. There is socially unprotected segments of the population in $87,9 \%$. Detection of cases of CRTL generally happens in case of the address of patients to the doctor $(57,9 \%)$ and in case of survey in a hospital concerning other disease $(35,2 \%)$. In accordance with the registration groups of CRTL patients with new cases $(37,4 \%)$, destructive process $(78,1 \%)$, bacterioexcretion $(98,3 \%)$, multirefractory tuberculosis $(76,3 \%)$ and an infiltrative clinical form $(71,8 \%)$ prevailed. While for today efficiency of treatment among the registered 1571 cases of CRTL in Zaporizhzhia region during 2012-2016 is low and made 25,6 \%, treatment is continued by another $27,4 \%$ of patients. The high percent of results of the interrupted and unsuccessful treatment $(17,6 \%)$ and the high frequency $(33,9 \%)$ transfer to palliative treatment of patients with treatment failure is concerning (in the general structure $-5,9 \%$ ).

Prospects of further scientific research. Studying of ways of rising of efficiency of treatment among patients with failures of treatment and the prevention of their development, assistance and the prevention of development of complications of tuberculosis by palliative TB patients.

Conflict of interests: no. 


\section{Referens}

1. Аналіз прогалин у лікуванні туберкульозу // Фінальний звіт у лікуванні туберкульозу. - http://stbcu.com.ua/2016/op-prog/

2. Берикова Э. А., Абубакиров А., Ракишева A. C., Бектасов C. Ж. Основные аспекты проблемы МЛУ/ШЛУ ТБ в Казахстане // Фтизиопульмонологя. - 2016. - Вып. 26, № 2. - С. 25-26.

3. Туберкульоз в Україні: Аналітично-статистичний довідник / ДУ «Український центр контролю за соціально-небезпечними хворобами МО3 України». - К.: «Бланк-Прес», 2015 . - http://www. slideshare.net/Ukraine CDC/201452881494

4. Украӥна. МОЗ. Уніфікований клінічний протокол первинної, вторинної (спеціалізованої) та третинної (високоспеціалізованої) медичної допомоги дорослим. Туберкульоз: наказ МО3 України № 620 від 31.12.2014 p. -171 c.

5. Циганкова Л. М. Туберкульоз із розширеною резистентністю мікобактерій до протитуберкульозних препаратів // Проф. медицина. - 2009. - № 1. - С. 61-64.

6. Черенько С. О. Проблема хіміорезистентного туберкульозу. - http://www.ifp.kiev.

ua/doc/ people/ tubrezist.htm

7. Ahuja S. D. , Ashkin D., Avendano M., Banerjee R., Bauer M., Bayona J. et al. Multidrug resistant pulmonary tuberculosis treatment regimens and patient outcomes: An individual patient data meta-analysis of 9,153 patients // PLoS Med. - 2012. - Vol. 9. - P. e10013002012e1001300. DOI: $10.1371 /$ journal.pmed.1001300.

8. Caminero J. A., García-Basteiro A. L., Rendon A. Multidrug-resistant tuberculosis // The Lancet. - 2019. - Vol. 394. - P. 298. DOI:10.1016/S0140-6736(19)30696-8.

9. Kurz S. G., Furin J. J., Bark Ch. M. Drug Resistant Tuberculosis: Challenges and Progress // Infect. Dis. Clin. North. Am. - 2016. - Vol. 30, N 2. - P. 509-522. DOI: 10.1016/j.idc.2016.02.010.

10. Millard James, Ugarte-Gil Cesar, Moore David A. J. Multidrug resistant tuberculosis // BMJ. 2015. - Vol. 350. - P. h882. DOI: 10.1136/bmj.h882.

11. Seung K. J., Keshavjee S., Rich M. L. Multidrug-Resistant Tuberculosis and Extensively DrugResistant Tuberculosis // Cold. Spring. Harb. Perspect. Med. - 2015. - Vol. 9, N 5. - P. a017863. DOI: $10.1101 /$ cshperspect.a017863.

12. WHO. Global Tuberculosis Report, 2015. - http://apps.who.int/iris/bitstream/10665/191102/1/9 789241565059_eng.pdf

13. WHO. Global Tuberculosis Report, 2018. Geneva, Switzerland: WHO, 2018.

14. WHO. Multidrug and extensively drug-resistant TB (M/XDR-TB): 2010 global report on surveillance and response [Text] / WHO/HTM/TB/2010.3. - Geneva, Switzerland: WHO, 2010.

\section{ЕФЕКТИВНІСТЬ АНТИМІКОБАКТЕРІАЛЬНОЇ ХІМІОТЕРАПІЇ В ЗАРЕЄСТРОВАНИХ ВИПАДКАХ ЗАХВОРЮВАННЯ НА ХІМІОРЕЗИСТЕНТНИЙ ТУБЕРКУЛЬОЗ ЛЕГЕНЬ У ЗАПОРІЗЬКІЙ ОБЛАСТІ}

\section{О. М. Разнатовська (Запоріжжя)}

Нині хіміорезистентний туберкульоз легень (ХРТЛ) є актуальною медико-соціальною проблемою як в Україні, так і в усьому світі. Встановлено, що на результат неефективного лікування хворих на туберкульоз легень впливають такі чинники: особливості туберкульозу, 
особисті характеристики хворих та їх соціальний статус, організація лікування. Мета дослідження - визначити ефективність антимікобактеріальної хіміотерапії в зареєстрованих випадках захворювання на ХРТЛ у Запорізькій області. Проведено аналіз зареєстрованого 1571 випадку захворювання на ХРТЛ у Запорізькій області за період 2012-2016 рр. Критеріями виключення були тяжкі супутні захворювання (ВІЛ-інфекція/СНІД, цукровий діабет тощо). Чоловіків було 75,1 \%, жінок - 24,9 \%. У структурі ХРТЛ достовірно превалюють особи чоловічої статі, особи зрілого і працездатного віку (44,4 і 92,3 \% відповідно). ХРТЛ достовірно частіше виявляли під час звернення хворих до лікаря $(57,9$ \%) та при обстеженні у стаціонарі з приводу іншого захворювання (35,2 \%). За реєстраційними групами ХРТЛ превалювали пацієнти 3 новими випадками захворювання $(37,4 \%)$ і рецидивами специфічного процесу $(26,5$ \%), деструктивним процесом (78,1%), бактеріовиділенням $(98,3$ \%), мультирезистентним туберкульозом (76,3 \%) та 3 інфільтративною клінічною формою (71,8 \%). Незважаючи на те, що нині ефективність лікування серед зареєстрованого 1571 випадку захворювання на ХРТЛ у Запорізькій області за період 2012-2016 рр. становить 25,6 \%, лікування продовжують ще 27,4 \% пацієнтів. Заслуговує на увагу високий відсоток результатів перерваного та невдалого лікування (по 17,6 \%) і висока частота (33,9 \%) переведення на паліативне лікування хворих з неефективним результатом лікування (в загальній структурі - 5,9\%).

Ключові слова: антимікобактеріальна хіміотерапія; хіміорезистентний туберкульоз; ефективність лікування.

\author{
ЭФФЕКТИВНОСТЬ АНТИМИКОБАКТЕРИАЛЬНОЙ \\ ХИМИОТЕРАПИИ В ЗАРЕГИСТРИРОВАННЫХ \\ СЛУЧАЯХ ХИМИОРЕЗИСТЕНТНОГО \\ ТУБЕРКУЛЁЗА ЛЁГКИХ \\ В ЗАПОРОЖСКОЙ ОБЛАСТИ
}

\title{
E. Н. Разнатовская (Запорожье)
}

В настоящее время химиорезистентный туберкулёз лёгких (ХРТЛ) является актуальной медико-социальной проблемой как в Украине, так и во всём мире. Установлено, что на результат неэффективного лечения больных туберкулёзом лёгких влияют следующие факторы: особенности туберкулёза, личностные характеристики больных и их социальный статус, организация лечения. Цель исследования - определить эффективность антимикобактериальной химиотерапии в зарегистрированных случаях заболевания ХРТЛ в Запорожской области. Проведён анализ зарегистрированного 1571 случая заболевания ХРТЛ в Запорожской области за период 2012-2016 гг. Критериями исключения были тяжёлые сопутствующие заболевания (ВИЧ-инфекция/СПИД, сахарный диабет и др.). Мужчин было 75,1%, женщин - 24,9 \%. В структуре ХРТЛ достоверно преобладали лица мужского пола, лица зрелого и трудоспособного возраста (44,4 и 92,3 \% соответственно). ХРТЛ достоверно чаще выявляли во время обращения больных к врачу $(57,9 \%)$ и при обследовании в стационаре по поводу другого заболевания $(35,2$ \%). По регистрационным группам ХРТЛ преобладали пациенты с новыми случаями заболевания $(37,4 \%)$ и рецидивами специфического процесса $(26,5 \%)$, деструктивным процессом (78,1 \%), бактериовыделением (98,3\%), мультирезистентным туберкулёзом $(76,3 \%)$ и с инфильтративной клинической формой $(71,8 \%)$. Несмотря на то, что в настоящее время эффективность лечения среди зарегистрированного 1571 случая заболевания ХРТЛ в Запорожской области за период 2012-2016 гг. составляет 25,6 \%, лечение продолжают ещё 27,4 \% пациентов. Обращается внимание на высокий процент результатов прерванного и неэффективного лечения (по 17,6 \%) и высокая частота $(33,9$ \%) перевода на паллиативное лечение больных с неудовлетворительным результатом лечения (в общей структуре $5,9 \%)$.

Ключевые слова: антимикобактериальная химиотерапия; химиорезистентный туберкулёз; эффективность лечения. 